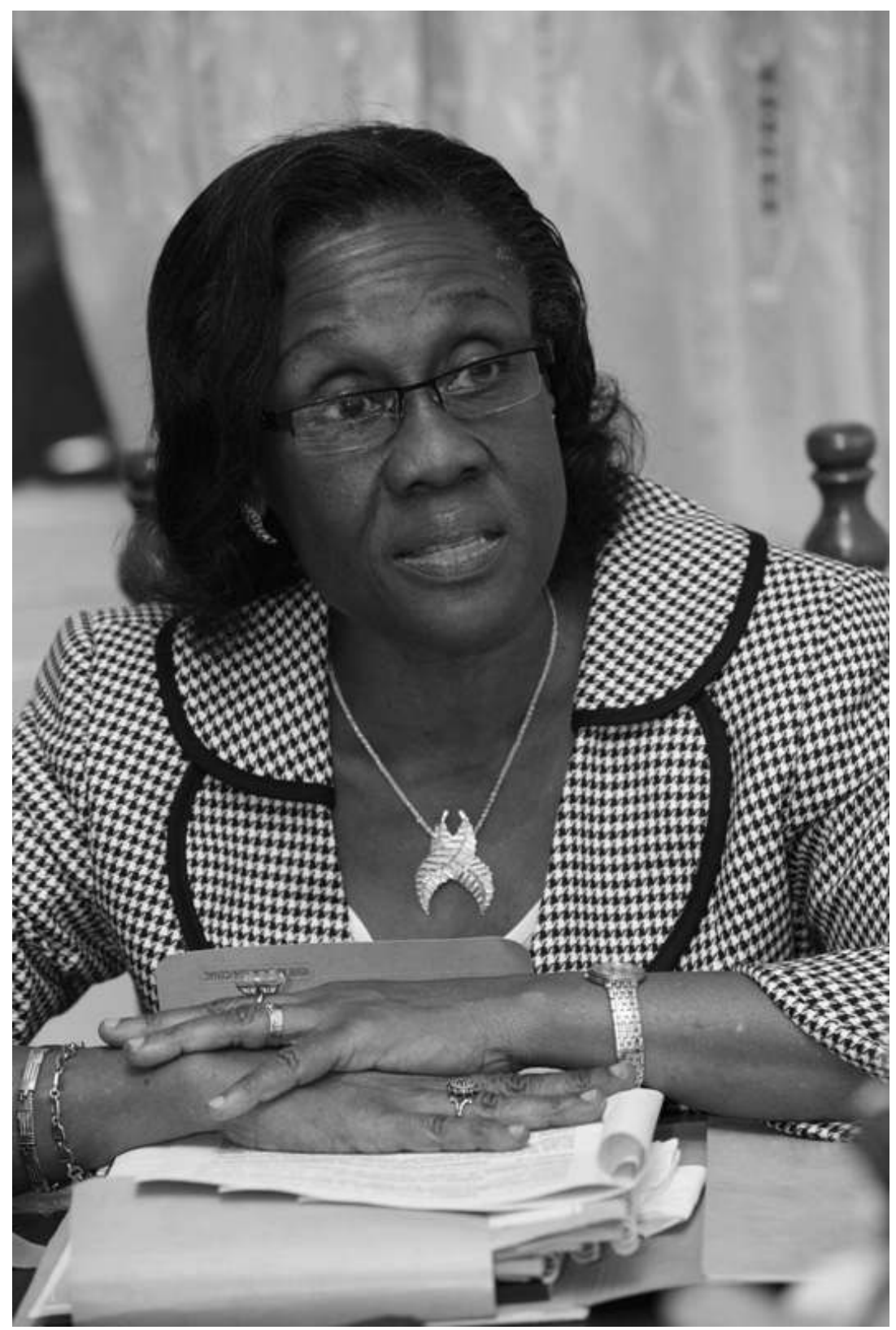

\title{
Tribute to Professor Elizabeth Annan-Yao
}

\section{Former Executive Director of the Union for African Population Studies}

Prof. Elizabeth Annan-Yao became a member of the Union for African Population Studies (UAPS) in 1990. She was elected to serve in the UAPS' Governing Council from 1996 to 1999. She became the Union's Executive Director in 2004 until 2008, when she left to become the Executive Director of the "Institut de Formation et de Recherche Démographique" (IFORD) in Cameroon. 
Since the time that Prof. Annan-Yao joined UAPS to her untimely death, she served the Union selflessly and with unparalleled commitment. She was among the first to step up and assist in coordinating various functions of the Union. In fact, she was more like the mother of UAPS rather than a mere member or employee of the union. Her remarkable dedication to the Union was best demonstrated when she took over the position of Executive Director of the Union in Dakar Senegal. The future of the union was very uncertain then, and the secretariat was hugely understaffed. She worked extra hard in these difficult conditions and she successfully negotiated with the Government of Ghana to set up the Union's headquarters in Accra and for the allocation of free office space at the National Population Council from which the Union operated from January 2007 until April 20I0. The moving of the headquarters and securing of the office space in Accra probably saved the Union from going into extinction!

As she did during the two years when she headed UAPS in Dakar, Prof. Annan-Yao single-handedly managed the Ghana office, with very skeletal support staff. As she was settling in Ghana, she played an instrumental role in the organization of the very successful Fifth African Population Conference, which was held in Arusha, Tanzania, in December 2007. During this conference, the Union paid special tribute to Prof Anna-Yao for her outstanding and selfless contributions to the Union.

Prof Annan Yao was also an outstanding scholar and leader on the global stage. She was a member of Governing Council for the International Union for the Scientific Study of Population between 2006 and 2009, where she ably represented the interests of the African continent. She was a distinguished scholar and teacher, and she made lasting contributions to the field of Demography and Population Studies, and their linkages to gender and sustainable development in Africa. She published widely on population, gender, and development issues; her latest books published in 2005 were titled: "Gender, Economies and Entitlements in Africa" and "Democracy and Development in West Africa. Myth and Reality".

Despite her vey busy schedule and responsibilities at IFORD, Prof Anna-Yao continued to serve UAPS tirelessly and advise the Secretariat on various issues up to the time that she passed on last month. She was a member of the International Scientific Committee that is organizing the Sixth African Population Conference, scheduled for December 20I I. A few weeks before she passed on, she sent a message to the Secretariat, suggesting four sessions, and offering to organize some of these if necessary. Her last message to the secretariat was on February $16^{\text {th }}, 2011$ when she ended her message with the words "I hope you find these comments useful. "Bon courage" in the preparations of the 6th APC. All the best, Elizabeth".

It is no wonder that members of the UAPS Governing Council, the Secretariat, and all members of UAPS around the world were extremely shocked to learn about her 
death a few weeks later. She was a pillar of strength for the Union, and we will all miss her dearly and profoundly for she was an accommodating and pleasant colleague, a strong-willed and independent scholar, a fighter for gender equity, a committed and selfless employee, and a god-fearing professional. She will especially be missed as a "professional mother" and teacher to the hundreds of young people that she taught and mentored throughout her impeccable career and colorful life.

May her soul rest in eternal peace.

Eliya Msiyaphazi Zulu (PhD.)

President, UAPS 